\title{
Vernalization and photoperiod-related changes in the DNA methylation state in winter and spring rapeseed
}

\author{
Justyna Guzy-Wrobelska • Maria Filek • Agnieszka Kaliciak • \\ Iwona Szarejko · Ivana Macháčková · Jan Krekule • \\ Mirosława Barciszewska
}

Received: 25 April 2012/Revised: 21 September 2012/Accepted: 15 October 2012/Published online: 31 October 2012

(C) The Author(s) 2012. This article is published with open access at Springerlink.com

\begin{abstract}
Vernalization-induced flowering is an effect of the epigenetic regulation of gene expression through DNA methylation and histone modifications. Vernalizationmediated silencing of a floral repressor through histone modifications was shown in Arabidopsis thaliana. However, for Brassica napus L., the mechanism underlying vernalization is unclear, and the roles of DNA methylation and histone modifications have not been established. This study revealed the profiles of changes in the DNA methylation state during vernalization (after 14, 35, 56 days) and the subsequent growth in long- or short-day photoperiods (after 2, 7, 14 days) in the winter and spring rapeseed
\end{abstract}

Communicated by L. A. Kleczkowski.

Electronic supplementary material The online version of this article (doi:10.1007/s11738-012-1126-4) contains supplementary material, which is available to authorized users.

J. Guzy-Wrobelska $(\bowtie) \cdot$ A. Kaliciak · I. Szarejko

Department of Genetics, University of Silesia,

Jagiellońska 28, 40-032 Katowice, Poland

e-mail: justyna.guzy-wrobelska@us.edu.pl

M. Filek

Institute of Plant Physiology, Polish Academy of Sciences,

Podlużna 3, 30-239 Kraków, Poland

M. Filek

Institute of Biology, Pedagogical University,

Podbrzezie 3, 30-320 Kraków, Poland

I. Macháčková · J. Krekule

Institute of Experimental Botany, Academy of Sciences

of the Czech Republic, Rozvojová 135,

16502 Prague, Czech Republic

M. Barciszewska

Institute of Bioorganical Chemistry, Polish Academy

of Sciences, Z. Noskowskiego 12/14, 61-704 Poznań, Poland using TLC and MSAP techniques. TLC analysis showed a significant decrease in the amount of 5-methylcytosine $\left(\mathrm{m}^{5} \mathrm{C}\right)$ in genomic DNA in both cultivars at the beginning of vernalization, but upon its termination, the winter rape showed a reduced level of $\mathrm{m}^{5} \mathrm{C}$ contrary to a significantly increased level in the spring rape. MSAP analysis revealed that winter and spring rapeseed differed in the MSAP loci which were demethylated/methylated in the course of the experiment and presented diverse profiles of changes in the methylation state. The winter rape showed permanent demethylations at $69.2 \%$ of MSAP loci in the course of vernalization that were mostly preserved upon its termination. The spring rape showed similar numbers of demethylations and methylations that were mainly transient. The study provides evidence of the role of DNA methylation in vernalization for rapeseed and for the significant prevalence of demethylations at the beginning of vernalization, which is necessary for the transition to reproductive growth.

Keywords Brassica napus . DNA methylation . MSAP · TLC · Vernalization

\author{
Abbreviations \\ $\mathrm{m}^{5} \mathrm{C} \quad$ 5-Methylcytosine \\ MSAP Methylation-sensitive amplification polymorphism \\ TLC Thin-layer chromatography
}

\section{Introduction}

Vernalization is the acquisition of the competence to flower resulting from exposure to the prolonged cold of the winter 
season (Chouard 1960, as cited by Schmitz et al. 2008). It ensures that flowering occurs in the appropriate season (spring) of the year in order to maximize reproductive success. A vernalization requirement is the key component of the reproductive strategy in many plant species, including the temperate cereals, Beta vulgaris, rapeseed and Arabidopsis thaliana (L.) Heynh.

Vernalization-induced flowering is considered to be an effect of the epigenetic regulation of gene expression which involves DNA methylation and histone modifications. In winter-annual accessions of Arabidopsis vernalization results in epigenetic, repressive modifications of the histones at chromatin of a floral repressor, FLOWERING LOCUS C (FLC; Bastow et al. 2004). Histone methylations at FLC are mediated by Polycomb Repressive Complex 2 (PRC2) to which VERNALIZATION INSENSITIVE 3 (VIN3) protein is recruited (Wood et al. 2006). A long intronic noncoding RNA (COLD ASSISTED INTRONIC NONCODING RNA, COLDAIR) is also required for the stable repression of FLC after cold. COLDAIR is transcribed from the first intron of $F L C$ during vernalization and it targets PRC2 to the FLC chromatin (Heo and Sung 2011). For the mitotically stable repression of $F L C$, the presence of LIKE HETEROCHROMATIN PROTEIN 1 (LHP1) is also required (Kim and Sung 2012). The expressions of UPSTREAM OF FLC (UFC), DOWNSTREAM OF FLC (DFC) and MADS AFFECTING FLOWERING1-5 (MAF1-MAF5) are also regulated by vernalization (Finnegan et al. 2004; Sheldon et al. 2009).

Conversely, vernalization has to be followed by exposure to an increasing day length in Beta vulgaris L. Vernalization-induced flowering is controlled in sugar beet by the interplay of two paralogues of FLOWERING LOCUS T (FT) from the photoperiod pathway in Arabidopsis. BvFT2, a promoter of flowering, is the orthologue of FT. In contrast, $B v F T 1$ evolved into a repressor which prevents the expression of $B v F T 2$ before vernalization. $B v F T 1$ is stably down-regulated by vernalization and the subsequent longday photoperiod that induces flowering. This mechanism of the vernalization response probably arose through gene duplication in the genus Beta (Pin et al. 2010). The role of another gene, B. vulgaris FLC-Likel ( $B v F L 1)$, the orthologue of $F L C 1$, in this process has not been elucidated, but its splicing variant, $B v F L 1 \_v 3$, is down-regulated by exposure to cold in transgenic Arabidopsis (Reeves et al. 2007).

In Brassicaceae species, with the exception of Arabidopsis, the role of DNA methylation and histone modifications in vernalization-induced flowering is still unclear. Although Brassica napus L. is closely related to Arabidopsis, they differ substantially. B. napus is amphidiploid with segmental chromosomal duplications which may result in multiple copies of genes that occur only once in
Arabidopsis. This may lead to functional differentiation and establish novel mechanisms of gene regulation (King et al. 2010). The role of the FLC orthologue in modifying flowering time was proved in $B$. napus (Tadege et al. 2001), but the results from Brassica oleracea L. have indicated that the expression of the FLC orthologue may involve a different regulatory mechanism from the one established for Arabidopsis. B. oleracea is of the plantvernalization responsive type, and therefore their plants have to reach a certain developmental stage before becoming sensitive to a low temperature. In contrast, Arabidopsis is of the seed-vernalization responsive type and is sensitive to low temperatures during seed germination (Lin et al. 2005).

DNA methylation of promoters and coding regions of genes have been found to be crucial in regulating plant development and organ or tissue differentiation (King et al. 2010). Vernalization-induced histone modifications at the FLC chromatin in Arabidopsis are not associated with changes in DNA methylation at this locus (Finnegan et al. 2005). However, a reduced level of DNA methylation after vernalization was shown for Arabidopsis (Finnegan et al. 1998), Nicotiana tabacum L. and Triticum aestivum L. (Sherman and Talbert 2002). It was also shown that the methylation state of DNA is intimately linked to chromatin structure and vice versa (Lindroth et al. 2004). Therefore, it was suggested that vernalization might also result in DNA demethylation and the active state of specific genes involved in the induction of flowering (Lizal and Relichova 2001; Filek et al. 2006b).

The extent and pattern of $\mathrm{m}^{5} \mathrm{C}$ in DNA can be measured using different methods (Barciszewska et al. 2007). Cellulose thin-layer chromatography (TLC) is a fast, simple and highly sensitive approach for the quantitative measurement of the total genomic levels of $\mathrm{m}^{5} \mathrm{C}$ in DNA. Unlike high-performance liquid chromatography (HPLC), it is a two-dimensional technique which requires only a limited amount of DNA and can clearly distinguish the contamination of a sample with RNA. It can be used for monitoring even slight changes in the methylation level in various biological processes (for details, Barciszewska et al. 2007). Methylation-sensitive amplification polymorphism (MSAP) is a modification of AFLP (Vos et al. 1995) with two restriction systems utilized in parallel: usually EcoRI/MspI and EcoRI/HpaII (Xu et al. 2000). EcoRI is insensitive to DNA methylation and cuts $5^{\prime}$-GAATTC-3' sites. MspI and HpaII are isoschizomers which differ in the ability to digest $5^{\prime}$-CCGG-3' sites, depending on their methylation state. MspI is still active when the internal $\mathrm{C}$ is methylated, but does not cut when the external $\mathrm{C}$ is methylated. HpaII can cut DNA when the external C is hemi-methylated, but the frequency of this restriction is much lower compared to the unmethylated site. Neither 
enzyme cuts when both $\mathrm{C}$ are methylated (McClelland et al. 1994). The technique allows changes in the methylation pattern within a subset of $5^{\prime}-\mathrm{CCGG}-3^{\prime}$ sites in the genome in plants at different developmental stages or the exposure to diverse environmental conditions to be investigated.

The aim of this study was to provide evidence of a role of DNA methylation in vernalization in rapeseed. The study demonstrated the changes in the DNA methylation state and pattern during vernalization and the subsequent growth in long- or short-day photoperiods in detail and provided the basis for a better understanding of the characteristic features and phases of this process in rapeseed. TLC analysis showed changes in global genomic DNA methylation, whereas MSAP analysis demonstrated detailed profiles of the methylation changes at MSAP loci in winter and spring rapeseed. This work is a solid foundation for a further study: the characterization of the selected MSAP loci and the identification of the genes that are probably involved in the vernalization response in rapeseed.

\section{Materials and methods}

Plant material and experimental design

Seeds of two rapeseed cultivars, a winter ('Górczański', G) and spring type ('Młochowski', M), were germinated as described in Filek et al. (2006b). Plants were grown in a growth chamber at $17 / 15^{\circ} \mathrm{C}$ (day/night, $16 \mathrm{~h}$ day) until the stage of a 5-leaf rosette and then transferred for 8 weeks (56 days) into $5 / 2{ }^{\circ} \mathrm{C}$ (day/night, $16 \mathrm{~h}$ day) for vernalization. After vernalization, plants were kept at $17 / 15^{\circ} \mathrm{C}$ (day/night) and exposed to a long (16 h day) or short ( $8 \mathrm{~h}$ day) photoperiod for 2 weeks. For the DNA extraction, apical parts of shoots $(0.3 \mathrm{~cm})$ were collected from plants before vernalization ( $\mathrm{V} 0$; reference point for vernalization) and after 14 (V14), 35 (V35) and 56 days (V56; reference point for subsequent treatments) of the cold treatment and upon its termination, during the growth in long- (LD) or short-day (SD) photoperiods after 2 (V56LD2 or V56SD2), 7 (V56LD7 or V56SD7) and 14 days (V56LD14 or V56SD14) under these conditions. The sampling points were chosen on the basis of a morphological observation of the developmental stage of shoot apical meristems (Filek et al. 2006a; Tarkowská et al. 2012), as follows: V0, V14-vegetative stage; V35-initiation of generative development, increase in cytokinin content; V56-generative stage with microscopy visible buds. These sampling points are crucial for comparing the changes that occur at the apical meristem during the induction of generative development.
Altogether, pools of the apical part of shoots (14-15 apices/sample) were collected at 10 points during the course of experiment for each cultivar.

\section{DNA extraction}

Total DNA was extracted using the micro C-TAB method according to Doyle and Doyle (1987). DNA concentration and quality were measured with a spectrophotometer (ND1000, NanoDrop Technologies, Wilmington, DE). Samples were diluted in sterile water to a concentration of $50 \mathrm{ng} / \mu \mathrm{l}$.

TLC chromatography of $5^{\prime}\left[\gamma-{ }^{32} \mathrm{P}\right]$-labeled nucleotides

Digestion of DNA samples, DNA digest labeling with $\left[\gamma-{ }^{32} \mathrm{P}\right]$ ATP, separation and identification of $\left[\gamma^{32} \mathrm{P}\right]$ 5-methyldeoxycytosine using two-dimensional cellulose TLC, as well as an intensity analysis were performed as described in Barciszewska et al. (2007). The analysis was performed on a Phosphoimager Typhoon (Pharmacia) with Image Quant Software. An example-scan of two-dimensional cellulose TLC was given in Online Resource 1 (ESM_1). The analysis was repeated three times and data were evaluated using the Statistica Anova Test (StatSoft Inc., Tulsa, USA) and presented as means with the standard deviation. Differences among means were detected using the Duncans multiple range tests. Values of $p \leq 0.05$ indicated the significance.

\section{MSAP}

In the MSAP technique EcoRI/MspI and EcoRI/HpaII restriction systems were used. The restriction, ligation, PCR preamplification, selective amplification and the visualization of products on a sequencer (Model 4300, LI-COR, Lincoln, NE) were as described in Filek et al. (2006b). The adapters for the EcoRI and MspI/HpaII recognition sites were as proposed by Vos et al. (1995) and Xu et al. (2000), respectively. For the preamplification step, the EcoRI primer E-A (5'-GACTGCGTACCAATTCA-3') and the MspI/HpaII primer MH-T (5'-GATGAGTC TAGAACGGT $\left.-3^{\prime}\right)$ were used, which bore one selective nucleotide at $3^{\prime}$ (in italic) of the basic sequence. For the selective amplification step, EcoRI and MspI/HpaII primers with three selective nucleotides added to the basic sequence at $3^{\prime}$ were used. Altogether, ten selective primer combinations were used (E-ACT/MH-TAC, E-ACT/MHTCA, E-ACT/MH-TGA, E-AAC/MH-TAG, E-AAC/MH-TA C, E-AAC/MH-TCA, E-AAC/MH-TGA, E-AAC/MH-TGC, E-AAG/MH-TCA, E-AAG/MH-TAC). An MSAP analysis was performed for each sample in two independent replications to ensure the repeatability of the band patterns. 
Table 1 Band patterns and methylation events that can be detected using MSAP after the digestion of two samples with $E c o \mathrm{RI} / M s p \mathrm{I}(\mathrm{E} / \mathrm{M})$ and $E c o \mathrm{RI} / H p a \mathrm{II}(\mathrm{E} / \mathrm{H})$ restriction systems

\begin{tabular}{|c|c|c|c|c|c|}
\hline \multirow[t]{3}{*}{ Locus type $^{a}$} & \multirow{2}{*}{\multicolumn{2}{|c|}{$\begin{array}{l}\text { Sample 1 } \\
\text { Band } \\
\text { pattern }^{\text {b }}\end{array}$}} & \multirow{2}{*}{\multicolumn{2}{|c|}{$\begin{array}{l}\text { Sample } 2 \\
\text { Band } \\
\text { pattern }^{\text {b }}\end{array}$}} & \multirow{3}{*}{$\begin{array}{l}\text { Changes in sample } 2 \\
\text { in relation to sample } 1^{\circ}\end{array}$} \\
\hline & & & & & \\
\hline & $\mathrm{E} / \mathrm{M}$ & $\mathrm{E} / \mathrm{H}$ & $\mathrm{E} / \mathrm{M}$ & $\mathrm{E} / \mathrm{H}$ & \\
\hline M & 1 & 1 & 1 & 1 & None \\
\hline $\mathrm{P} 1$ & 1 & 0 & 1 & 0 & None \\
\hline $\mathrm{P} 2$ & 0 & 1 & 0 & 1 & None \\
\hline $\mathrm{P} 3 \mathrm{a}$ & 1 & 1 & 0 & 0 & Meth both $\mathrm{C}$ \\
\hline $\mathrm{P} 3 \mathrm{~b}$ & 1 & 1 & 1 & 0 & Meth int $\mathrm{C}$ \\
\hline $\mathrm{P} 3 \mathrm{c}$ & 1 & 1 & 0 & 1 & Meth ext $\mathrm{C}$ \\
\hline P3d & 1 & 0 & 0 & 0 & Meth ext $\mathrm{C}$ \\
\hline $\mathrm{P} 3 \mathrm{e}$ & 0 & 1 & 0 & 0 & Meth both $\mathrm{C}$ or int $\mathrm{C}$ \\
\hline $\mathrm{P} 4 \mathrm{a}$ & 0 & 0 & 1 & 1 & Demeth both $\mathrm{C}$ \\
\hline $\mathrm{P} 4 \mathrm{~b}$ & 0 & 0 & 1 & 0 & Demeth ext $\mathrm{C}$ \\
\hline $\mathrm{P} 4 \mathrm{c}$ & 0 & 0 & 0 & 1 & Demeth both or int $\mathrm{C}$ \\
\hline P4d & 0 & 1 & 1 & 1 & Demeth ext $\mathrm{C}$ \\
\hline $\mathrm{P} 4 \mathrm{e}$ & 1 & 0 & 1 & 1 & Demeth int $\mathrm{C}$ \\
\hline
\end{tabular}

${ }^{\text {a }} M$ monomorphic loci, not methylated; P1-P4 polymorphic loci with various numbers of methylated $\mathrm{C}$ at the $5^{\prime}$-CCGG- $3^{\prime}$ site; the same (P1-P2) versus different (P3-P4) methylation patterns in compared samples

b 1 presence of a band, $O$ absence of a band

c Meth methylated, demeth demethylated, int $C$ internal cytosine, ext $C$ external cytosine

\section{MSAP data analysis}

Clear bands on MSAP gels, ranging from 100 to $500 \mathrm{bp}$, were counted. The presence/absence of the amplification product in a single MSAP locus was scored in both restriction systems. Owing to the differential sensitivity of MspI and HpaII to the methylation state at $5^{\prime}$-CCGG- $3^{\prime}$ sites, it was possible to define whether a demethylation or methylation event had occurred in a single MSAP locus in the samples compared (for details, Filek et al. 2006b). Briefly, when two DNA samples are subjected to MSAP analysis, there are 13 possible band pattern combinations in a single MSAP locus between two samples compared. They can be divided into three main types (Table 1). Monomorphic (M) bands are present in both enzyme systems in the samples compared and refer to monomorphic MSAP loci, where the restriction occurred in both samples and in both restriction systems, which indicates a lack of methylation. Polymorphic bands of types P1-P2 are polymorphic for enzyme systems, but have the same methylation pattern in the samples compared. They identify MSAP loci methylated in the same way. Polymorphic bands of types P3-P4 describe loci methylated differentially in the samples compared. The type $\mathrm{P} 3 \mathrm{a}-\mathrm{e}$ band patterns indicate loci with a higher number of methylated $\mathrm{C}$ at $5^{\prime}$-CCGG-3' sites in sample 2 compared to sample 1 . This can result either from methylation of one or both Cs of the $5^{\prime}-\mathrm{CCGG}-3^{\prime}$ sites in sample 2 or demethylation of the respective positions in sample 1 . The type $\mathrm{P} 4 \mathrm{a}-\mathrm{e}$ band patterns represent loci with a higher number of methylated $\mathrm{C}$ at $5^{\prime}$-CCGG- ${ }^{\prime}$ sites in sample 1 than in sample 2. These patterns reflect demethylation events in sample 2 or methylation of the respective positions in sample 1.

\section{Results}

Changes in the total amount of $\mathrm{m}^{5} \mathrm{C}$ in DNA during the course of the experiment

In the TLC analysis, in the vegetative apices (at V0) similar percentages of $\mathrm{m}^{5} \mathrm{C}(\sim 3 \%)$ were detected in the genomic DNA in winter and spring rapes (Fig. 1a, b). During vernalization, initially (at V14) significant reductions in the total amount of $\mathrm{m}^{5} \mathrm{C}$ in DNA were detected in winter and spring rapes, reaching 58.0 and $57.8 \%$ of the rate of $\mathrm{m}^{5} \mathrm{C}$ at V0, respectively. Then, a progressive increase in the amount of $\mathrm{m}^{5} \mathrm{C}$ was observed at V35 (initiation of generative development) and V56 (generative stage). Despite this increase, at V56 the winter rape showed only $86.2 \%$ of the amount of $\mathrm{m}^{5} \mathrm{C}$ measured at $\mathrm{V} 0$, while in the spring rape the amount of $\mathrm{m}^{5} \mathrm{C}$ was significantly increased and reached $144.6 \%$ of the rate at V0 (Fig. 1a, b).

The transfer of the winter rape 'Górczański' to a warm temperature and growth in a long-day photoperiod produced at V56LD2 a slight decrease in the amount of $\mathrm{m}^{5} \mathrm{C}$ ( $71.8 \%$ of the rate at V0), followed by its slow, progressive increase, and at V56LD14 it reached $87.5 \%$ of the rate of $\mathrm{m}^{5} \mathrm{C}$ at $\mathrm{V0}$, and was similar to the rate attained on the last day of vernalization (V56; Fig. 1a). In the shortday photoperiod, the winter rape presented a continuous decrease in the amount of $\mathrm{m}^{5} \mathrm{C}$, and at V56SD14 its amount reached $52.5 \%$ of the rate of $\mathrm{m}^{5} \mathrm{C}$ detected at $\mathrm{V} 0$.

The spring rape 'Młochowski' generally showed similar trends in the changes in the amount of $\mathrm{m}^{5} \mathrm{C}$ as the winter rape during the growth in both photoperiods; however, a significantly wider amplitude of these changes was observed (Fig. 1b). The transfer of the spring rape to a warm temperature and the long-day photoperiod resulted at V56LD2 in a decrease in the amount of $\mathrm{m}^{5} \mathrm{C}$ to the rate observed in the vegetative apices ( $102 \%$ of the rate at $\mathrm{V} 0$ ). Then, a progressive increase in the amount of $\mathrm{m}^{5} \mathrm{C}$ was observed, and at V56LD14 it reached $138 \%$ of the rate of $\mathrm{m}^{5} \mathrm{C}$ at V0 (i.e., the rate similar to detected at V56). The transfer of the spring rape to a warm temperature and the short-day photoperiod initially (at V56SD2) produced a further, significant increase in the amount of $\mathrm{m}^{5} \mathrm{C}$ in 


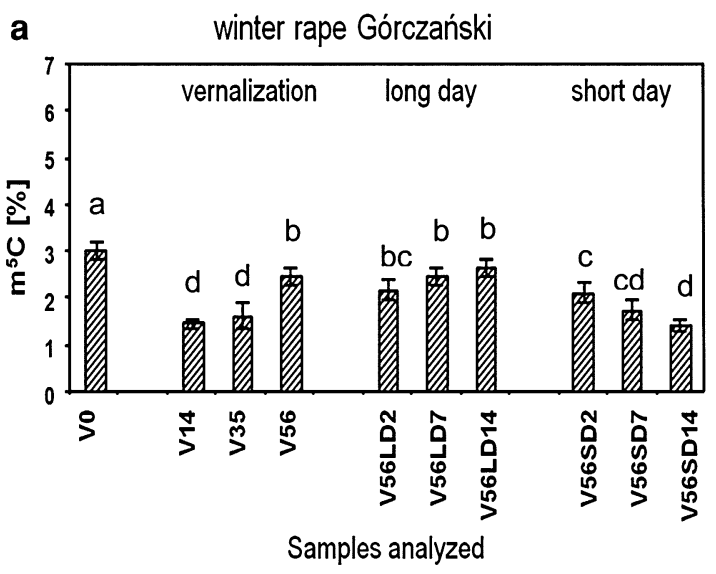

Fig. 1 a, b Percentage of 5-methylcytosine $\left(\mathrm{m}^{5} \mathrm{C}\right)$ in the DNA before (V0) and during vernalization (V14, V35, V56), and during the subsequent growth in long- (V56LD2, V56LD7, V56LD14) or short-

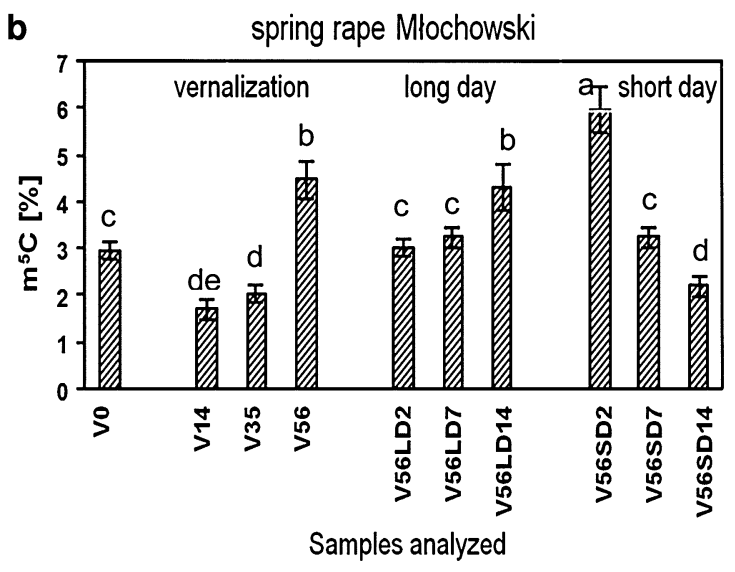

day (V56SD2, V56SD7, V56SD14) photoperiods in the winter (a) and spring (b) rapes. Different letters in each bar differ significantly from each other according to the Duncan test $(p \leq 0.05)$
Table 2 Number and types of MSAP loci detected in the analysis of winter and spring rape

a Description of P1-P4 symbols in the section "Materials and methods"

b 9 MSAP primer pairs used (without H-TCA/E-AAG)

\begin{tabular}{|c|c|c|c|c|c|c|}
\hline \multirow[t]{3}{*}{ Cultivar } & \multirow{3}{*}{$\begin{array}{l}\text { No. of } \\
\text { loci } \\
\text { analyzed }\end{array}$} & \multirow{3}{*}{$\begin{array}{l}\text { Monomorphic } \\
\text { loci (M) }\end{array}$} & \multicolumn{4}{|c|}{ Polymorphic loci ${ }^{\mathrm{a}}$} \\
\hline & & & \multirow[t]{2}{*}{ Total no. } & \multicolumn{2}{|c|}{$\begin{array}{l}\text { Characteristic for } \\
\text { enzymatic system }\end{array}$} & \multirow{2}{*}{$\begin{array}{l}\text { Related to } \\
\text { environmental } \\
\text { conditions } \\
\text { (P3 + P4) }\end{array}$} \\
\hline & & & & $\begin{array}{l}\text { EcoRI/MspI } \\
(\mathrm{P} 1)\end{array}$ & $\begin{array}{l}\text { EcoRI/ } \\
\text { HpaII (P2) }\end{array}$ & \\
\hline $\begin{array}{l}\text { ‘Górczański’ } \\
\text { (winter rape) }\end{array}$ & 574 & $401(69.9 \%)$ & $172(30.0 \%)$ & $110(19.2 \%)$ & $42(7.3 \%)$ & $20(3.5 \%)$ \\
\hline $\begin{array}{l}\text { ‘Młochowski' } \\
\text { (spring } \\
\text { rape) }{ }^{\mathrm{b}}\end{array}$ & 415 & $289(69.6 \%)$ & $126(30.4 \%)$ & $83(20.0 \%)$ & $27(6.5 \%)$ & $16(3.9 \%)$ \\
\hline
\end{tabular}

EcoRI/HpaII restriction systems (P1-P2 types), that is they were present in all samples in one of these systems. The winter rape showed $19.2 \%$ of MSAP loci characteristic for the EcoRI/MspI system and $7.3 \%$ for the EcoRI/HpaII system. In the spring rape these loci constituted 20.0 and $6.5 \%$, respectively. This type of polymorphism revealed methylation events not related to vernalization or growth in long- and short-day photoperiods. However, it enabled MSAP loci (5'-CCGG-3' sites) with fully or hemi-methylated internal $\mathrm{C}$ (band in $E c o \mathrm{RI} / \mathrm{Msp \textrm {I }}$ ) to be distinguished from those with hemi-methylated external $\mathrm{C}$ (band in EcoRI/HpaII). Thus, full or hemi-methylation of the internal $\mathrm{C}$ was much more frequent than hemi-methylation of the external $\mathrm{C}$ in both rapes. The most interesting group of polymorphic MSAP loci represented events where the presence or absence of a band differentiated samples collected from the same cultivar during the cold treatment (V0, V14, V35, V56) and the subsequent exposure to a long-day (V56LD2, V56LD7, V56LD14) or short-day photoperiod (V56SD2, V56SD7, V56SD14). These loci (P3-P4 types) constituted $3.5 \%$ in the winter rape and $3.9 \%$ in the spring rape (Table 2). They indicated changes in the methylation state that occurred during the course of the experiment.

Both cultivars showed about $30 \%$ of polymorphic bands (Table 2). Most of them differentiated the EcoRI/MspI and 
Table 3 Profiles of changes in the methylation state at MSAP loci during the cold treatment in winter and spring rape

\begin{tabular}{|c|c|c|c|c|c|c|c|c|c|}
\hline \multicolumn{5}{|c|}{ Winter rape 'Górczański' } & \multicolumn{5}{|c|}{ Spring rape 'Młochowski' } \\
\hline \multirow{2}{*}{$\begin{array}{l}\text { Reference } \\
\text { sample } \\
\text { V0 }\end{array}$} & \multicolumn{3}{|c|}{$\begin{array}{l}\text { Samples collected during } \\
\text { the cold treatment }{ }^{\mathrm{a}}\end{array}$} & \multirow[t]{2}{*}{ No. of MSAP loci } & \multirow{2}{*}{$\begin{array}{l}\text { Reference sample } \\
\text { V0 }\end{array}$} & \multicolumn{3}{|c|}{$\begin{array}{l}\text { Samples collected during } \\
\text { the cold treatment }{ }^{\mathrm{a}}\end{array}$} & \multirow[t]{2}{*}{$\begin{array}{l}\text { No. of MSAP } \\
\text { loci }\end{array}$} \\
\hline & V14 & V35 & V56 & & & V14 & V35 & V56 & \\
\hline M & $D$ & $D$ & $D$ & 3 & M & $D$ & $D$ & $D$ & 2 \\
\hline M & M & $D$ & $D$ & 6 & M & M & M & $D$ & 1 \\
\hline $\mathrm{D}$ & $M$ & $M$ & $M$ & 1 & $\mathrm{D}$ & $M$ & $M$ & $M$ & 2 \\
\hline $\mathrm{D}$ & $\mathrm{D}$ & $M$ & $M$ & 1 & - & - & - & - & - \\
\hline M & $D$ & M & M & 1 & M & $D$ & M & M & 2 \\
\hline M & M & $D$ & M & 1 & $\mathrm{D}$ & $\mathrm{D}$ & $M$ & $\mathrm{D}$ & 1 \\
\hline - & - & - & & - & $\mathrm{D}$ & $M$ & $\mathrm{D}$ & $\mathrm{D}$ & 1 \\
\hline
\end{tabular}

Profiles generated after a pair-wise comparison of MSAP loci (band presence vs. absence) in both restriction systems from samples collected before (V0) and during the cold treatment (V14, V35 or V56)

${ }^{a} M, D$ in italics methylation/demethylation event at an MSAP locus compared to the reference (V0); $M$, $D$ in roman font absence of a methylation/demethylation event at an MSAP locus compared to the reference (V0)

Changes in the methylation state during the cold treatment

A pair-wise comparison of the samples collected at V0 with those collected during the cold treatment at V14, V35 or V56 allowed the MSAP loci (P3-P4 types) related to vernalization to be identified and the profiles of changes in the methylation state characteristic for the winter and spring rapes to be generated (Table 3 ). In the winter rape 'Górczański', 13 loci showed changes in the methylation state during vernalization, and they were permanent in 11 loci. An evident tendency towards demethylation was observed in the majority of them (9): at V14 (3 loci) or V35 (6 loci). Only 2 loci underwent methylation (at V14 or V35), and 2 other loci showed transient changes: demethylation at V14 or V35 followed by methylation at V35 or V56, respectively. In the spring rape 'Młochowski', a lower number of loci (9) expressed changes in the methylation state during the cold treatment, and it was not possible to observe any apparent tendency of changes. In 3 loci permanent demethylations were noticed at V14 (2 loci) or V56 (1 locus) of the cold treatment, whereas 2 loci presented permanent methylations from V14. Four other loci underwent transient changes in the methylation state. Of these, 2 loci showed demethylations at V14 and methylations once again at V35, while in 2 other loci the opposite situation took place, that is methylations at V14 or V35 followed by demethylations at V56.

Changes in the methylation state during growth in a long- or short-day photoperiod

The stability of the changes in DNA methylation that occurred during the cold treatment was investigated during the subsequent growth in the long- or short-day photoperiod. Profiles of changes were generated based on pair-wise comparisons of the samples collected at the end of the cold treatment (V56) with the samples collected during the long-day (V56LD2, V56LD7, V56LD14) or short-day (V56SD2, V56SD7, V56SD14) photoperiod. During the long-day photoperiod, the winter rape 'Górczański' expressed changes in the methylation state at seven loci. Only two loci showed a permanent increase in the methylation state (at V56LD2 or V56LD7), whereas the remaining five loci presented transient methylations at V56LD7. Thus, the level of demethylation attained during vernalization was maintained (Table 4). In the spring rape 'Młochowski', a slightly larger number of loci with changes in the methylation state (10) were detected during the long-day photoperiod and no apparent trend in changes was found (Table 4). A permanently increased methylation state at two loci (at V56LD2) and the permanently increased demethylation state at three loci were detected (at V56LD2 or V56LD14). The other five loci presented transient and divergent changes in the methylation state, leading to temporarily increased demethylation at V56LD7 (2 loci) or methylation at V56LD2, V56LD7 or V56LD14 (3 loci; Table 4).

During the short-day photoperiod, the winter rape presented changes in the methylation state at 12 loci (Table 5). All the changes occurred during the first week under the short-day conditions. In contrast to the growth in the longday photoperiod, these changes were permanent in almost all loci, and an evident trend towards an increased methylation level (8 loci) was identified at V56SD2 (5 loci) or V56SD7 (3 loci). Only two loci underwent demethylations at V56SD2 or V56SD7. Two other loci showed transient changes in the methylation state, that is, a temporarily increased demethylation or methylation at V56SD2 or V56SD7, respectively. In the spring rape seven loci 
Table 4 Profiles of changes in the methylation state at MSAP loci during growth in the long-day photoperiod subsequent to the cold treatment for winter and spring rape

\begin{tabular}{|c|c|c|c|c|c|c|c|c|c|}
\hline \multicolumn{5}{|c|}{ Winter rape 'Górczański' } & \multicolumn{5}{|c|}{ Spring rape 'Młochowski' } \\
\hline \multirow{2}{*}{$\begin{array}{l}\text { Reference } \\
\text { sample } \\
\text { V56 }\end{array}$} & \multicolumn{3}{|c|}{$\begin{array}{l}\text { Samples collected in the } \\
\text { long-day photoperiod }\end{array}$} & \multirow[t]{2}{*}{$\begin{array}{l}\text { No. of MSAP } \\
\text { loci }\end{array}$} & \multirow{2}{*}{$\begin{array}{l}\text { Reference } \\
\text { sample } \\
\text { V56 }\end{array}$} & \multicolumn{3}{|c|}{$\begin{array}{l}\text { Samples collected in the } \\
\text { long-day photoperiod }^{\mathrm{a}}\end{array}$} & \multirow[t]{2}{*}{$\begin{array}{l}\text { No. of MSAF } \\
\text { loci }\end{array}$} \\
\hline & V56LD2 & V56LD7 & V56LD14 & & & V56LD2 & V56LD7 & V56LD14 & \\
\hline $\mathrm{D}$ & $M$ & $M$ & $M$ & 1 & $\mathrm{D}$ & $M$ & $M$ & $M$ & 2 \\
\hline $\mathrm{D}$ & $\mathrm{D}$ & $M$ & $M$ & 1 & - & - & - & - & - \\
\hline- & - & - & - & - & M & $D$ & $D$ & $D$ & 2 \\
\hline- & - & - & - & - & M & M & M & $D$ & 1 \\
\hline $\mathrm{D}$ & $\mathrm{D}$ & $M$ & $\mathrm{D}$ & 5 & $\mathrm{D}$ & $\mathrm{D}$ & $M$ & $\mathrm{D}$ & 1 \\
\hline- & - & - & - & - & $\mathrm{D}$ & $M$ & $M$ & $\mathrm{D}$ & 1 \\
\hline- & - & - & - & - & $\mathrm{D}$ & $M$ & $\mathrm{D}$ & $M$ & 1 \\
\hline- & - & - & - & - & $\mathrm{M}$ & $\mathrm{M}$ & $D$ & $\mathrm{M}$ & 2 \\
\hline
\end{tabular}

Profiles generated after a pair-wise comparison of MSAP loci (band presence vs. absence) in both restriction systems between samples collected at V56 of the cold treatment and at V56LD2, V56LD7 or V56LD14 of the long-day photoperiod

${ }^{a} M, D$ in italics methylation/demethylation event at an MSAP locus compared to the reference (V56); $M$, D in roman font absence of a methylation/demethylation event at an MSAP locus compared to the reference (V56)

Table 5 Profiles of changes in the methylation state at MSAP loci during growth in the short-day photoperiod subsequent to the cold treatment for winter and spring rape

\begin{tabular}{|c|c|c|c|c|c|c|c|c|c|}
\hline \multicolumn{5}{|c|}{ Winter rape 'Górczański' } & \multicolumn{5}{|c|}{ Spring rape 'Młochowski' } \\
\hline \multirow{2}{*}{$\begin{array}{l}\text { Reference } \\
\text { sample } \\
\text { V56 }\end{array}$} & \multicolumn{3}{|c|}{$\begin{array}{l}\text { Samples collected in the } \\
\text { short-day photoperiod }^{\mathrm{a}}\end{array}$} & \multirow[t]{2}{*}{$\begin{array}{l}\text { No. of MSAP } \\
\text { loci }\end{array}$} & \multirow{2}{*}{$\begin{array}{l}\text { Reference } \\
\text { sample } \\
\text { V56 }\end{array}$} & \multicolumn{3}{|c|}{$\begin{array}{l}\text { Samples collected in the } \\
\text { short-day photoperiod }^{\mathrm{a}}\end{array}$} & \multirow[t]{2}{*}{$\begin{array}{l}\text { No. of MSAP } \\
\text { loci }\end{array}$} \\
\hline & V56SD2 & V56SD7 & V56SD14 & & & V56SD2 & V56SD7 & V56SD14 & \\
\hline $\mathrm{D}$ & $M$ & $M$ & $M$ & 5 & $\mathrm{D}$ & $M$ & $M$ & $M$ & 4 \\
\hline $\mathrm{D}$ & $\mathrm{D}$ & $M$ & $M$ & 3 & - & - & - & - & - \\
\hline M & $D$ & $D$ & $D$ & 1 & M & M & M & $D$ & 1 \\
\hline M & M & $D$ & $D$ & 1 & - & - & - & - & - \\
\hline $\mathrm{D}$ & $\mathrm{D}$ & $M$ & $\mathrm{D}$ & 1 & - & - & - & - & - \\
\hline $\mathrm{M}$ & $D$ & $\mathrm{M}$ & $\mathrm{M}$ & 1 & $\mathrm{M}$ & $D$ & $\mathrm{M}$ & $\mathrm{M}$ & 2 \\
\hline
\end{tabular}

Profiles generated after a pair-wise comparison of MSAP loci (band presence vs. absence) in both restriction systems from samples collected at V56 of the cold treatment and at V56SD2, V56SD7 or V56SD14 of the short-day photoperiod

${ }^{a} M, D$ in italics methylation/demethylation event at an MSAP locus compared to the reference (V56); $M, D$ in roman font absence of a methylation/demethylation event at an MSAP locus compared to the reference (V56)

presented changes in the methylation state under the shortday conditions (Table 5). Among them, a permanent increase in the methylation state was observed at four loci at V56SD2, and three other loci showed increased demethylation-transient (2 loci at V56SD2) or permanent (1 locus at V56SD14).

MSAP loci related to the cold treatment and diverse photoperiod conditions

For the MSAP loci which underwent permanent changes during the course of the experiment, profiles of the changes in methylation state were created. This comparison enabled groups of MSAP loci attributed to the analyzed environmental conditions to be identified. (1) Loci related to vernalization where the methylation changes were maintained after it ended; (2) loci related to the growth in the long- or short-day photoperiod with the changes in methylation that were not preserved after the chilling period or that were changed exclusively in one of the photoperiods; and (3) loci that underwent the same changes in the methylation state in both photoperiods and they could be related to the plants transfer to the temperature of $17 / 15^{\circ} \mathrm{C}$ (Table 6).

In the winter rape, out of 11 loci with permanent changes in the methylation state during vernalization, 10 loci (8 demethylated and 2 methylated) or 8 loci 
Table 6 MSAP loci related to the cold treatment, long- and short-day photoperiods and the transfer to a warm temperature in the winter and spring rape

\begin{tabular}{|c|c|c|c|c|c|c|c|c|c|}
\hline \multirow{2}{*}{$\begin{array}{l}\text { MSAP loci with } \\
\text { methylation changes }\end{array}$} & \multicolumn{3}{|c|}{ Methylation profile ${ }^{\mathrm{a}, \mathrm{b}}$} & \multicolumn{3}{|c|}{$\frac{\text { Winter rape 'Górczański' }}{\text { No. of loci }}$} & \multicolumn{3}{|c|}{$\frac{\text { Spring rape 'Młochowski' }}{\text { No. of loci }}$} \\
\hline & V0 & V56 & $\begin{array}{l}\text { V56LD14 or } \\
\text { V56SD14 }\end{array}$ & $\begin{array}{l}\text { LD } \\
\text { only }\end{array}$ & $\begin{array}{l}\text { SD } \\
\text { only }\end{array}$ & $\begin{array}{l}\text { LD and SD } \\
\text { shared }\end{array}$ & $\begin{array}{l}\text { LD } \\
\text { only }\end{array}$ & $\begin{array}{l}\text { SD } \\
\text { only }\end{array}$ & $\begin{array}{l}\text { LD and SD } \\
\text { shared }\end{array}$ \\
\hline \multirow{2}{*}{$\begin{array}{l}\text { During CT and preserved } \\
\text { after its end }\end{array}$} & M & $D$ & $\mathrm{D}$ & 3 & 1 & 5 & - & - & 2 \\
\hline & $\mathrm{D}$ & $M$ & M & - & - & 2 & - & 1 & - \\
\hline \multirow{2}{*}{$\begin{array}{l}\text { During CT and } \\
\text { not preserved } \\
\text { after its end }\end{array}$} & M & $D$ & $M$ & 1 & 3 & - & - & 1 & 1 \\
\hline & $\mathrm{D}$ & $M$ & $D$ & - & - & - & 1 & - & 1 \\
\hline \multirow{2}{*}{$\begin{array}{l}\text { At } 17 / 15{ }^{\circ} \mathrm{C} \text { after the end of } \\
\text { CT }\end{array}$} & M & M & $D$ & - & 2 & - & 1 & - & - \\
\hline & $\mathrm{D}$ & $\mathrm{D}$ & $M$ & - & 4 & 1 & - & 1 & 2 \\
\hline
\end{tabular}

${ }^{a}$ Profiles generated after a pair-wise comparison of MSAP loci (band presence vs. absence) in both restriction systems from samples collected before (V0) and at V56 of cold treatment, and from samples collected at V56 of cold treatment and under long- (at V56LD14) or short-day photoperiod (at V56SD14)

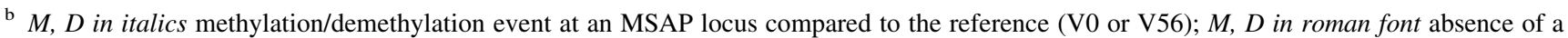
methylation/demethylation event at an MSAP locus compared to the reference (V0 or V56)

$L D, S D$ long-/short-day photoperiod, $C T$ cold treatment

(6 demethylated and 2 methylated) maintained their methylation state during the growth in long- or short-day photoperiod, respectively (Table 6). These changes can be considered to be an effect of vernalization that is preserved in the subsequent, specific growing conditions. Special attention should be paid to 7 of these loci (5 demethylated and 2 methylated) which were common for both photoperiods, and thus seem to be strongly attributed to vernalization. In addition, one locus related to growth in long-day photoperiod was identified. This locus became demethylated during vernalization but after it ended underwent methylation. However, a significantly larger group of loci (9) could be attributed to the growth of the winter rape in the short-day photoperiod following vernalization. Under this condition three loci that were demethylated during vernalization, once again became methylated and six other loci underwent specific methylations (4 loci) or demethylations (2 loci). Finally, one locus, which was unchanged during vernalization, underwent permanent methylation in both photoperiods, and this might be related to the transfer to the temperature of $17 / 15^{\circ} \mathrm{C}$.

In the spring rape, mostly transient changes in the methylation state were observed at MSAP loci during the course of the experiment, thus they were not taken into account in this comparison (Table 6). Out of five loci that underwent permanent changes in the methylation state during the chilling period, two demethylated loci maintained their state regardless of the later, divergent photoperiod conditions, and one locus that was methylated during the chilling period preserved its state in short-day photoperiod. These three loci might be considered as related to the cold treatment of the spring rape. As to the loci specifically attributed to the growth in different photoperiods, two loci that became demethylated in the longday conditions were identified for the spring rape, and one of them had been earlier methylated during the chilling period. In contrast, in the short-day photoperiod, one locus that underwent methylation exclusively in this environment was observed. Finally, the group of loci attributed to the transfer to the temperature of $17 / 15^{\circ} \mathrm{C}$ comprised one locus that was demethylated and one locus that was methylated during the chilling period that did not preserve these changes in both photoperiods, as well two loci that were unchanged during the cold treatment and underwent methylation in both photoperiods.

\section{Discussion}

DNA methylation is one of the epigenetic modifications that take place in the nucleosome at different levels through reversible biochemical reactions (Yaish et al. 2011). It plays a key role in regulating gene expression patterns in plant growth and development; in response to different environmental factors; in defending against transposon proliferation or in genomic imprinting (Yan et al. 2010). Failure of the DNA methylation control, such as hypermethylation or hypomethylation of DNA, can result in a wide range of abnormal phenotypes, tumor development or the activation of potential oncogenes and transposable elements (King et al. 2010). The role of DNA methylation in the control of gene expressions was shown by genome-wide cytosine methylation mapping. Only $\sim 5$ and $8.1 \%$ of promoters of the expressed genes were 
methylated, respectively, in Arabidopsis and rice, whereas $\sim 33$ and $31.2 \%$ of their active genes were still methylated within transcribed regions (Zhang et al. 2006; Yan et al. 2010). In contrast, $16.3 \%$ of inactive genes and $34.4 \%$ of transposable element (TE)-related genes in rice were methylated in their promoters and to a much higher extent compared to the active genes, and $\sim 66 \%$ of TE-related genes were methylated in their gene bodies. The methylation of promoters is suspected to lead to transcriptional repression, especially for tissue-specific genes (Zhang et al. 2006), but the function of gene body methylation remains unclear. However, it was suggested recently that it can also affect gene expression (Teixeira and Colot 2009).

The DNA demethylation in a phase change was reported in Pinus radiata D. Don (Fraga et al. 2002), and dissimilarities in the DNA methylation level among plants sampled at different ages were shown in Linum usitatissimum L. (Brown et al. 2008). In contrast, studies in A. thaliana showed that vernalization-induced flowering involves the epigenetic, repressive histone modifications at the FLC locus (Sheldon et al. 2009). However, in addition to histone modifications, a reduced level of DNA methylation after vernalization was shown in Arabidopsis (Finnegan et al. 1998), as well as in $N$. tabacum and T. aestivum L. (Sherman and Talbert 2002). A close relationship between DNA methylation and chromatin structure was recently demonstrated by the finding that nucleosome-bound DNA was more highly methylated than flanking DNA (Chodavarapu et al. 2010). Possibly, DNA demethylation in response to vernalization affects promoter or coding regions, and thereby activates specific genes which take part in the repression of the FLC locus, thus enabling flowering (Dennis and Peacock 2007).

Our study revealed the differences in the total amount of $\mathrm{m}^{5} \mathrm{C}$ in the DNA and in the methylation pattern at $5^{\prime}$-CCGG$3^{\prime}$ sites (MSAP loci) during the cold treatment between winter and spring rapes. Both cultivars showed a significant decrease in the total amount of $\mathrm{m}^{5} \mathrm{C}$ in DNA at the beginning of the cold treatment which was followed by its progressive increase. They differed, however, in the amplitude of this increase, and at the end of the treatment the winter rape still showed a reduced level of $\mathrm{m}^{5} \mathrm{C}$, in contrast to a significantly increased level in the spring rape. These results were reflected by the MSAP analysis. The winter rape showed mainly permanent demethylations $(69.2 \%)$ at MSAP loci which occurred in the first half of the cold treatment. These loci seemed to be strongly related to vernalization-induced flowering in the winter rape, as these changes were preserved during the subsequent growth in both photoperiods. In contrast, the spring rape showed at MSAP loci a similar number of demethylations and methylations, often transient. It appears that a prevalence of genomic-wide demethylations at the beginning of vernalization is necessary for a transfer to reproductive growth for winter rapeseed as well as to switch on the genes involved in the induction of flowering. In turn, the lower number of changes in the methylation state at MSAP loci and the increased overall amount of $\mathrm{m}^{5} \mathrm{C}$ at the end of the exposure to cold might be the result of the fixation of a specific methylation pattern characteristic for the reproductive growth.

These results confirmed the authors' previous analysis, which suggested the presence of MSAP loci with changes in the methylation state specific for vernalization and a significant prevalence of demethylation events during the cold treatment in the winter rape (Filek et al. 2006b). The importance of the first weeks of a prolonged exposure to cold was also suggested. A stimulating effect on the induction of flowering in winter rape was shown for some chemical and physical factors only when plants were first exposed to cold for 10-14 days (Filek et al. 2002). Recently, variations in methylation level in the shoot apical meristem and the presence of hypermethylation and hypomethylation phases in the course of vernalization have been reported in sugar beet (Trap-Gentil et al. 2011).

The study also investigated differences in the level and pattern of DNA methylation between the winter and spring rape during growth in long- or short-day photoperiods subsequent to the cold treatment. The growth in the longday photoperiod, after the initial decrease in the amount of $\mathrm{m}^{5} \mathrm{C}$, resulted in a similar rate of $\mathrm{m}^{5} \mathrm{C}$ to that attained in vernalization in both rapes (TLC approach). As to the MSAP loci, in the case of the winter rape, the growth in the long-day photoperiod also resulted in the maintenance of the methylation state attained in vernalization, as mostly transient methylations were observed, while in the spring rape mostly permanent methylations and demethylations at MSAP loci were detected. In the case of winter rape, growth in the long-day photoperiod following vernalization is a natural strategy, and it appears that its reproductive growth proceeded. For spring rape, the prolonged cold treatment could be a stress factor which triggered the demethylation and methylation events at loci, which needed to be reprogrammed upon its termination. Dynamic changes in DNA methylation have been proposed as a way of actively reprogramming the epigenome (Zhang et al. 2010).

Growth under the short-day photoperiod, which can be treated as an abiotic stress factor, resulted in a significant, continuous decrease in the total amount of $\mathrm{m}^{5} \mathrm{C}$ in the genomic DNA for both rape cultivars. In the MSAP analysis, the changes in the methylation state were observed mostly at the beginning of this treatment-mainly permanent methylations in the winter rape and a similar number of permanent methylations and transient demethylations in the spring rape. The MSAP results obtained for growth during the short-day photoperiod are in opposition not only to the TLC results of this work, but also to quantitative 
analysis carried out on a photoperiod supersensitive genotype of Oryza sativa L. where mostly demethylations were observed in the short-day photoperiod (Thanananta et al. 2006). However, unlike rapeseed, rice is a short-day species. Nevertheless, the MSAP analysis revealed loci which underwent changes in the methylation state exclusively in long- or short-day photoperiods, or else, after the transfer to a warm temperature regardless of the photoperiod being applied. Such loci might be involved in a response to these specific environmental factors. An MSAP analysis in Perilla frutescens showed that the DNA methylation state in $21 \%$ of MSAP fragments was altered by photoperiodic conditions (Kondo et al. 2010). The exposure of plants to diverse, abnormal temperatures or photoperiods can be a strong stress factor. Changes in the level of DNA methylation in MSAP analyses were reported in response to various environmental factors or treatments (Tatra et al. 2000; Labra et al. 2004; Baranek et al. 2010). In rapeseed, the methylation/demethylation events at MSAP loci were the result of the salt stress (Lu et al. 2007) and in Zea mays roots a genome-wide demethylation was observed under cold stress (Steward et al. 2002).

In the study, we provide evidence of the role of DNA methylation in vernalization for rapeseed and establish detailed profiles of the changes in the methylation state and pattern in the course of vernalization and growth in diverse photoperiods for winter and spring rapes. The MSAP technique proved useful in detecting loci which might be related to the vernalization process. This is a solid foundation for further characterization of the selected MSAP in order to identify the genes involved in the vernalization response in rapeseed.

Author contribution M. Filek, I. Szarejko and I. Macháčková designed the experiments and coordinated results interpretation; M. Filek and J. Krekule cultivated plant material and collected samples. M. Barciszewska was responsible for TLC analysis and its results interpretation. J. Guzy-Wrobelska and A. Kaliciak extracted DNA, ran the MSAP analysis and analyzed the data. J. Guzy-Wrobelska wrote the paper. M. Filek, I. Szarejko and I. Macháčková were involved in the final preparation of the paper.

Open Access This article is distributed under the terms of the Creative Commons Attribution License which permits any use, distribution, and reproduction in any medium, provided the original author(s) and the source are credited.

\section{References}

Baranek M, Krizan B, Ondrusikova E, Pidra M (2010) DNAmethylation changes in grapevine somaclones following in vitro culture and thermotherapy. Plant Cell Tiss Organ Cult 101:11-22

Barciszewska MZ, Barciszewska AM, Rattan SIS (2007) TLC-based detection of methylated cytosine application to aging epigenetics. Biogerontology 8:673-678

Bastow R, Mylne JS, Lister C, Lippman Z, Martienssen RA, Dean C (2004) Vernalization requires epigenetic silencing of FLC by histone methylation. Nature 427:164-167

Brown JCL, De Decker MM, Fieldes MA (2008) Comparative analysis of developmental profiles for DNA methylation in 5-azacytidine-induced early-flowering flax lines and their control. Plant Sci 175:217-225

Chodavarapu RK, Feng S, Bernatavichute YV, Chen PY, Stroud H, $\mathrm{Yu}$ Y et al (2010) Relationship between nucleosome positioning and DNA methylation. Nature 466:388-392

Chouard P (1960) Vernalization and its relations to dormancy. Annu Rev Plant Physiol 11:191-238

Dennis ES, Peacock WJ (2007) Epigenetic regulation of flowering. Curr Opin Plant Biol 10:528-533

Doyle JJ, Doyle JL (1987) A rapid DNA isolation procedure for small quantities of fresh leaf tissue. Phytoch Bulletin 19:11-15

Filek M, Biesaga-Kościelniak J, Marcińska I, Krekule J, Macháčková I (2002) Direct electric current partly replaces the chilling effect in vernalization of winter wheat. J Plant Physiol 159:795-797

Filek M, Biesaga-Kościelniak J, Marcińska I, Macháčková I, Krekule J, Dubert F (2006a) Electric current affects the rate of development in isolated apical part sof rape in vitro. Biol Plant 50:465-468

Filek M, Janiak A, Szarejko I, Grabczyńska J, Macháčková I, Krekule J (2006b) Does DNA methylation pattern mark generative development in winter rape? Z Naturforsch 61:387-396

Finnegan EJ, Genger RK, Kovac K, Peacock WJ, Dennis ES (1998) DNA methylation and the promotion of flowering by vernalization. Proc Natl Acad Sci USA 95:5824-5829

Finnegan EJ, Sheldon CC, Jardinaud F, Peacock WJ, Dennis ES (2004) A cluster of Arabidopsis genes with a coordinate response to an environmental signal. Curr Biol 14:911-916

Finnegan EJ, Kovac KA, Jaligot E, Sheldon CC, Peacock WJ, Dennis ES (2005) The down-regulation of FLOWERING LOCUS C (FLC) expression in plants with low levels of DNA methylation and by vernalization occurs by distinct mechanisms. Plant $\mathbf{J}$ 44:420-432

Fraga MF, Canal MJ, Rodriguez R (2002) Phase-change related epigenetic and physiological changes in Pinus radiata D Don. Planta 215:672-678

Heo JB, Sung S (2011) Vernalization-mediated epigenetic silencing by a long intronic noncoding RNA. Science 331:76-79

Kim D-H, Sung S (2012) Environmentally coordinated epigenetic silencing of FLC by protein and long noncoding RNA components. Curr Opin Plant Biol 15:51-56

King GJ, Amoah S, Kurup S (2010) Exploring and exploiting epigenetic variation in crops. Genome 53:856-868

Kondo H, Shiraya T, Wadaa KC, Takeno K (2010) Induction of flowering by DNA demethylation in Perilla frutescens and Silene armeria: heritability of 5-azacytidine-induced effects and alteration of the DNA methylation state by photoperiodic conditions. Plant Sci 178:321-326

Labra M, Grassi F, Imazio S, Di Fabio T, Citterio S, Sgorbati S, Agradi E (2004) Genetic and DNA-methylation changes induced by potassium dichromate in Brassica napus L. Chemosphere 54:1049-1058

Lin S-I, Wang J-G, Poon S-Y, Su C-L, Wang S-S, Chiou T-J (2005) Differential regulation of FLOWERING LOCUS C expression by vernalization in cabbage and Arabidopsis. Plant Physiol 137:1037-1048 
Lindroth AM, Shultis D, Jasencakova Z, Fuchs J, Johnson L, Schubert D, Patnaik D, Pradhan S, Goodrich J, Schubert I, Jenuwein T, Khorasanizadeh S, Jacobsen SE (2004) Dual histone H3 methylation marks at lysines 9 and 27 required for interaction with CHROMOMETHYLASE3. EMBO J 23:4286-4296

Lizal P, Relichova J (2001) The effect of day-length, vernalization and DNA methylation on the flowering time in Arabidopsis thaliana. Physiol Plant 113:121-127

Lu G, Wu X, Chen B, Gao G, Xu K (2007) Evaluation of genetic and epigenetic modification in rapeseed (Brassica napus) induced by salt stress. J Integr Plant Biol 49:1599-1607

McClelland M, Nelson M, Rashke E (1994) Effect of site-specific modification on restriction endonucleases and DNA modification methyltransferases. Nucl Acid Res 22:3640-3659

Pin PA, Benlloch R, Bonnet D, Wremerth-Weich E, Kraft T, Gielen JJL, Nilsson O (2010) An antagonistic pair of FT homologs mediates the control of flowering time in sugar beet. Science 330:1397

Reeves PA, He Y, Schmitz RJ, Richard M. Amasino RA, Panella LW, Richards CM (2007) Evolutionary conservation of the FLOWERING LOCUS C-mediated vernalization response: evidence from the Sugar Beet (Beta vulgaris). Genetics 176:295-307

Schmitz RJ, Sung S, Amasino RM (2008) Histone arginine methylation is required for vernalization-induced epigenetic silencing of FLC in winter-annual Arabidopsis thaliana. Proc Natl Acad Sci USA 105:411-416

Sheldon CC, Finnegan EJ, Peacock WJ, Dennis ES (2009) Mechanisms of gene repression by vernalization in Arabidopsis. Plant J 59:488-498

Sherman JD, Talbert LE (2002) Vernalization-induced changes of the DNA methylation pattern in winter wheat. Genome 45:253-260

Steward N, Ito M, Yamaguchi Y, Koizumi N, Sano H (2002) Periodic DNA methylation in maize nucleosomes and demethylation by environmental stress. J Biol Chem 277:37741-37746

Tadege M, Sheldon CC, Helliwell CA, Stoutjesdijk P, Dennis ES, Peacock WJ (2001) Control of flowering time by FLC orthologues in Brassica napus. Plant J 28:545-553

Tarkowská D, Filek M, Biesaga-Kościelniak J, Marcińska I, Macháčková I, Krekule J, Strnad M (2012) Cytokinins in shoot apices of Brassica napus plants during vernalization. Plant Sci 187:105-112
Tatra GS, Miranda J, Chinnappa CC, Reid DM (2000) Effect of light quality and 5-azacytidine on genomic methylation and stem elongation in two ecotypes of Stellaria longipes. Physiol Plant 109:313-321

Teixeira FK, Colot V (2009) Gene body DNA methylation in plants: a means to an end or an end to a means? EMBO J 28:997-998

Thanananta T, Pongtongkam P, Thongpan A, Kaveeta L, Peyachoknagul S (2006) Effect of short day photoperiod on DNA methylation and expression of a gene in rice KDML105. Afric $\mathbf{J}$ Biotech 5:1275-1782

Trap-Gentil M-V, Hebrard C, Lafon-Placette C, Delaunay A, Hagege D, Joseph C, Brignolas F, Lefebvre M, Barnes S, Maury S (2011) Time course and amplitude of DNA methylation in the shoot apical meristem are critical points for bolting induction in sugar beet and bolting tolerance between genotypes. J Exp Bot 62:2585-2597

Vos P, Hogers R, Bleeker M, Reijans M, van de Lee T, Hornes M, Fritjers A, Pot J, Peleman J, Kuiper M, Zabeau M (1995) AFLP: a new technique for DNA fingerprinting. Nucl Acids Res 23:4407-4414

Wood CC, Robertson M, Tanner G, Peacock WJ, Dennis ES, Helliwell CA (2006) The Arabidopsis thaliana vernalization response requires a polycomb-like protein complex that also includes VERNALIZATION INSENSITIVE 3. Proc Natl Acad Sci USA 103:14631-14636

Xu M, Li X, Korban SS (2000) AFLP-based detection of DNA methylation. Plant Mol Biol Rep 18:361-368

Yaish MW, Colasanti J, Rothstein SJ (2011) The role of epigenetic processes in controlling flowering time in plants exposed to stress. J Exp Bot 62:3727-3735

Yan H, Kikuchi S, Neumann P, Zhang W, Wu Y, Chen F, Jiang J (2010) Genome-wide mapping of cytosine methylation revealed dynamic DNA methylation patterns associated with genes and centromeres in rice. Plant $\mathrm{J}$ 63:353-365

Zhang X, Yazaki J, Sundaresan A, Cokus S, Chan SW-L, Chen H, Henderson IR, Shinn P, Pellegrini M, Jacobsen SE, Ecker JR (2006) Genome-wide high-resolution mapping and functional analysis of DNA methylation in Arabidopsis. Cell 126:1189-1201

Zhang M, Kimatu JN, Xu K, Liu B (2010) DNA cytosine methylation in plant development. J Gen Genomics 37:1-12 